The 3rd International Conference on Biological Science 2013

(The 3rd ICBS-2013)

\title{
ISOLATION OF UPSTREAM AND DOWNSTREAM FRAGMENT OF ACYLTRANSFERASE (AT3) GENE FROM Capsicum frutescens L. CV. CAKRAHIJAU
}

Andi Madihah Manggabarani, Ria Reinnata Juliandari, Elhah Nailul Khasna, Shelly Zairina, Eko Sri Sulasmi, and Dwi Listyorini

Department of Biology, Faculty of Mathematics and Natural Science StateUniversity of Malang, Jl. Semarang 5, Malang, Indonesia E-mail: andimadihah@yahoo.com; listyorini.alj@bio.um.ac.id

\begin{abstract}
Capsicum frutescens cv. CakraHijau is a local cultivar that has been widely cultivated in Indonesia due to its several advantages, including its pungency. Pungent taste of Capsicum is generated by capsaicin compound encoded by AT3 gene. Recently, $404 \mathrm{bp}$ fragment of $A T 3$ gene had been isolated. This research aimed to isolate upstream and downstream fragments of $A T 3$ gene. PCR method used two pairs of primers: F2/R2 (F25'-TCT CCA TGC TGA CAA CAA CA-3', and R25'-CGATGAAAG ATA GCT TGT G-3') and F3/R3 ( $F 3$ 5'-GCA TCT CTT GCA GAG AGC ATA G-3', and R3 5'-TGT ACG CAC TCG TTG AGA CT-3'). F2/R2 primers amplified 326 bp upstream fragments, while F3/R3 primer amplified 261 bp downstream fragments. The alignment of those two fragments with one previously obtained produces a 675 bp partial sequence with 230 bp located upstream of presumed start codon. Clustal $X$ analysis reveals that this fragment is located upper half compare to $C$. frutescens cv. Shuanla AT3 gene. Further primer design is necessary to obtain downstream of $A T 3$ gene.
\end{abstract}

Key words: Capsicum frutescens cv. CakraHijau, Capsaicin, AT3 gene

\section{INTRODUCTION}

Capsicum frutescens $\mathrm{L}$. is a member of Solanaceae's family which is widely cultivated in Indonesia (Djarwaningsih, 2005). One local cultivar of the $C$. frutescens L. is CakraHijau. This cultivar has a high economic value for its high level of pungency and resistancy against disease (Rukmana, 2002).

The pungency of Capsicum frutescens L. comes from a secondary metabolite named capsaicin (Stewart et al., 2007). Capsaicin is syntheses in leaf and accumulated in placenta of fruit (Stewart et al., 2005). The biosynthesis of capsaicin involves two secondary metabolic pathways; there are phenylpropanoid and fatty acid pathway (Stewart et al., 2005). In capsaicin biosynthesis there is an enzyme which combine phenillylamine and 8-methyl-6nonenoic acid forming Capsaicin. This enzyme is Capsaicin Synthase (CS) (Stewart et al., 2005), encoded by Acyltransferase gene (AT3) (Kim et al., 2001).

AT3 gene had been reported for three species i.e Capsicum annum, Capsicum chinense, and Capsicum frutescens (Stewart et al., 2005). For Capsicum frutescens's AT3 had been reported from Capsicum frutescens cv. BG 2814-6 and Capsicum frutescens cv.Shuanla and partial segment of Capsicum frutescens cv. CakraHijau (Habibi et al., 2013).

Previous research on Capsicum frutescens cv.CakraHijau reported 404 bp length middle fragment of AT3 compared to Capsicum frutescens cv. BG 2814-6 and Capsicum frutescens cv.Shuanla (Habibi et al., 2013). This research was aimed to isolate an upstream and a 
downstreamfragment of $A T 3$ based on sequent of the fragment already revealed.

\section{MATERIALS AND METHODS}

Total DNA of Capsicum frutescens cv. CakraHijau was isolated according to the procedure of Nucleospin $\Theta$ // plant DNA isolation kit (Macherey-Nage) with slight modification. AT3 fragments isolation was performed by PCR method. The primers designed based on AT3 sequences of Capsicum frutescens cv. CakraHijau previously reported (Habibi et al., 2013). The primers used are $F 2$ 5'-TGC TGA TCT CCA CAA CAA CA-3', R2 5'-GCT ATA AAG TGA CGA TGT G-3', F3 5'-GCA TCT CTT GCAAGC ATA GAG G-3 ', and R3 5'-TGT TCG TTG ACG CAC AGA CT-3'. PCR cycles for F2/R2 is as follow: denaturation $94^{\circ} \mathrm{C}$ for 1 min, annealing $52^{\circ} \mathrm{C}$ for $1 \mathrm{~min}$, and extension $72^{\circ} \mathrm{C}$ for $1 \mathrm{~min}$. PCR cycles for F3/R3 is as follow : denaturation $94^{\circ} \mathrm{C}$ for $1 \mathrm{~min}$, annealing $55^{\circ} \mathrm{C}$ for $1 \mathrm{~min}$, and extension $72^{\circ} \mathrm{C}$ for $1 \mathrm{~min}$. PCR products were checked using $1,5 \%$ agarose gel electrophoresis and sequenced by the Big Dye Transluminator through ABI 3130 Genetic analyzer machine at Eijkman Institute for Molecular Biology Jakarta. The sequencing results was analyzed using DNA Baser, BLAST, Clustal X software, and SIXFRAME.

\section{RESULTS AND DISCUSSION}

In this research, F2/R2 primers pair obtained 326 bp upstream (Figure 1A), meanwhile F3/R3 primers pairs obtained 261 bp downstream fragments relative to $A T 3$ gene fragment had been previously isolated (Figure 1B).
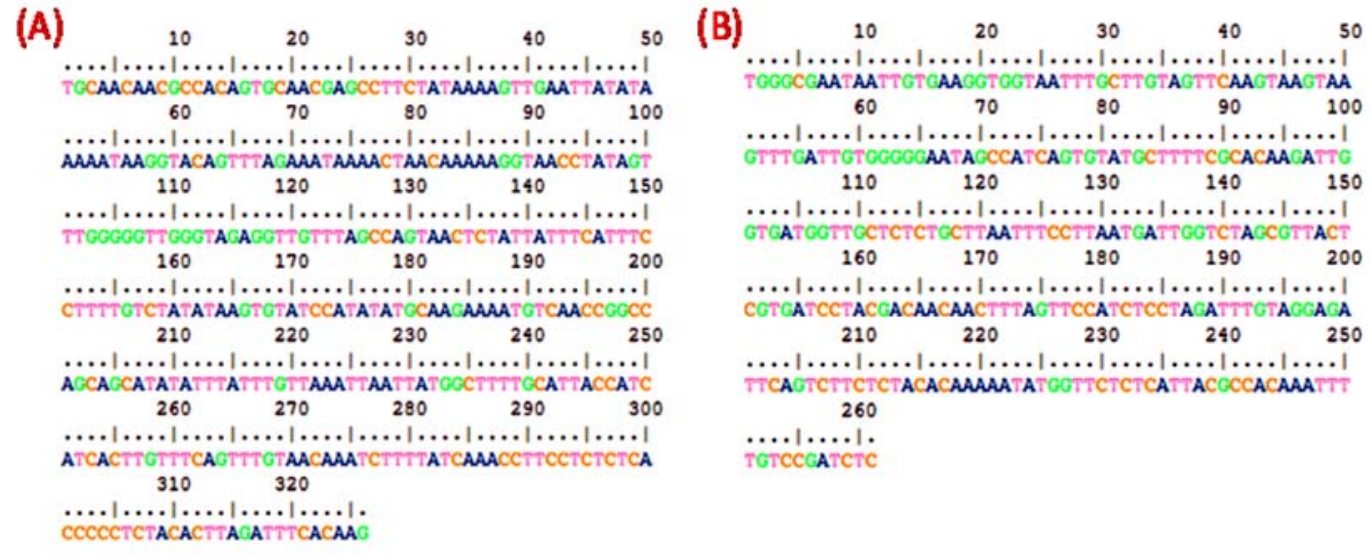

Figure 1. AT3 gene consensus sequence isolated from $C$. frutescens $\mathrm{cv}$. CakraHijau using pair of primers: (A) F2/R2; (B) F3R3

BLAST analysis results shows that the query coverage of $F 2 / R 2$ fragment is $8 \%$ and $5 \%$ of the total $A T 3$ sequence of $C$. frutescens cv. BG2814-6 and $C$. frutescens cv. Shuanla, respectivelty; and sharing $99 \%$ and $98 \%$ similarity with $A T 3$ of $C$. frutescens cv. BG2814-6 and $C$. frutescens $\mathrm{Cv}$. Shuanla, respectively for (Figure 2).

BLAST analysis results of $F 3 / R 3$ fragments shows query coverage of $7 \%$ and $17 \%$ from total sequence of $C$. frutescens cv. BG2814- 6 and $C$. frutescens cv. Shuanla AT3 gene, respectively; and sharing $96 \%$ and $95 \%$ similarity compared to $C$. frutescens cv. BG2814-6 and $C$. frutescens $\mathrm{cv}$. ShuanlaAT3gene, respectively (Figure 3 ). 


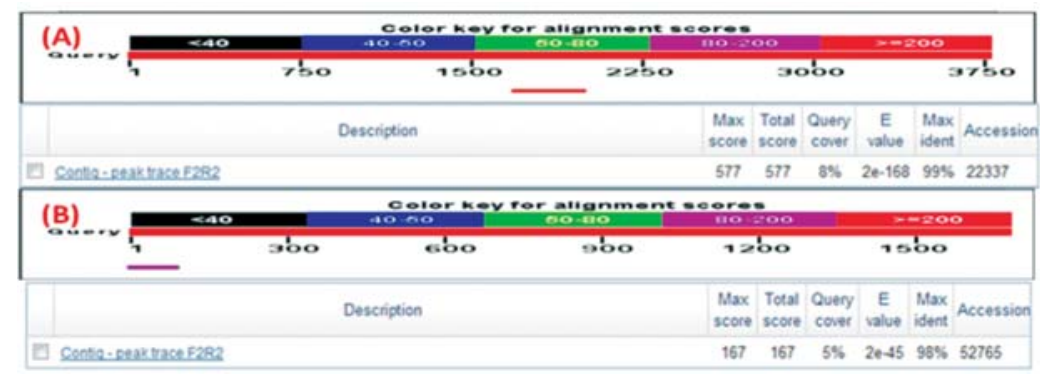

Figure 2. BLAST analysis result of C. frutescens cv. CakraHijauAT3 gene obtained by F2/R2 primers compared to AT3 of : A. C. frutescens cv. BG2814-6; B. C. frutescens cv. Shuanla

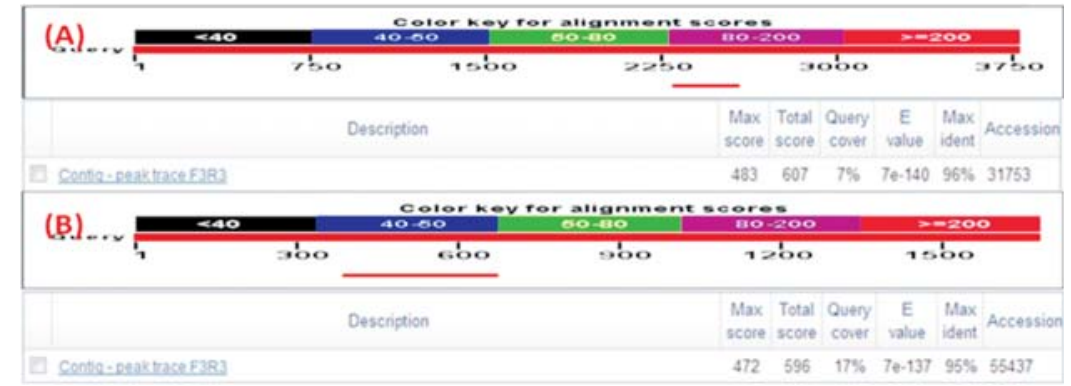

Figure 3. BLAST analysis result of $\mathrm{C}$. frutescens cv. CakraHijauAT3 gene obtained by F3/R3 primers compared to AT3 of : A. C. frutescens cv. BG2814-6; B. C. frutescens cv. Shuanla

The result of merging the $F 2 / R 2$ and $F 3 / R 3$ fragments with previously obtained fragments (F1/R1) of $A T 3$ from $C$. frutescens cv. CakraHijau resulted on 905 bp length fragment which arranged as follow: nucleotide 1 to 326 is F2/R2 fragment, nucleotide 327 to 646 is $F 1 / R 1$ fragment, and nucleotide 646 to 905 is $F 3 / R 3$ fragment. Open reading frame analysis reveal that ORF \#3 is the most possible reading frame of the target gene since it is contained no stop codon in the middle of the fragment (Figure 4).

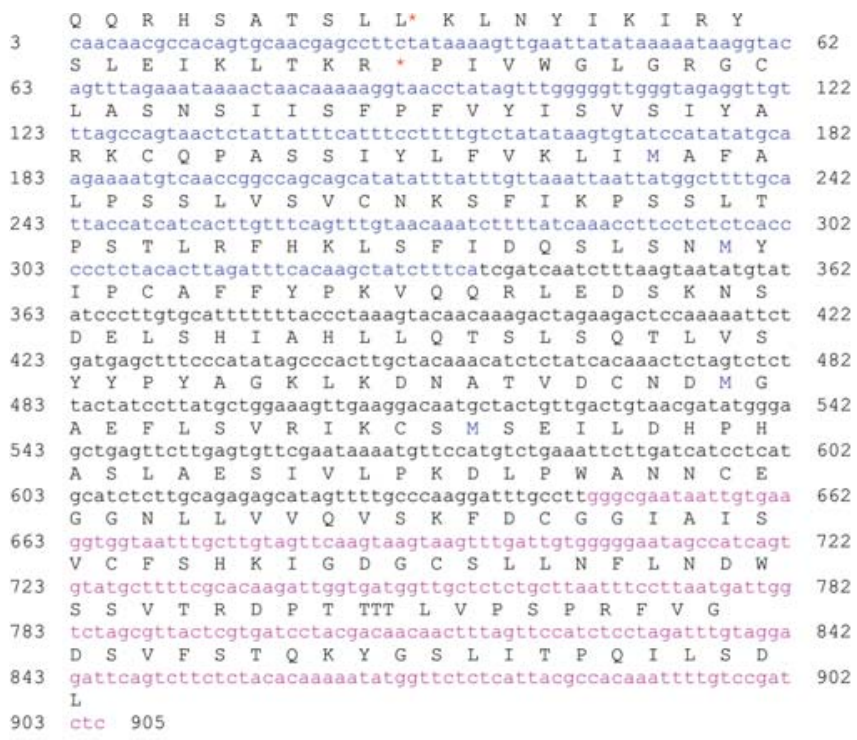

Figure 4. The third ORF of complete fragment of merged F2/R2 (Blue font) and F3/R3 (Pink font) into the previously obtained $F 1 / R 1$ fragments (Black font) of $C$. frutescens $c v$. CakraHijau AT3. Red asterisk depict STOP codon; M: Methionin or START codon. 
The result of BLAST analysis of merged $F 1 / R 1-F 2 / R 2-F 3 / R 3$ sequence compared to AT3 gene of $C$. frutescenscv. Shuanla and $C$. frutescenscv. BG 2814-6 shows that the fragment spends $675 \mathrm{bp}$ and $905 \mathrm{bp}$ of total AT3 length from both references, respectively. Moreover, BLAST result also shows that the query coverage of that target genes compared to $A T 3$ complete sequence of $C$. frutescens cv. BG 2814-6 and $C$. frutescens cv. Shuanla are $24 \%$ and $40 \%$, respectively, with $99 \%$ similarity level to both references sequence (Figure 5). These results give more confident that the successfully isolated fragments are correctly parts of $A T 3$ gene.

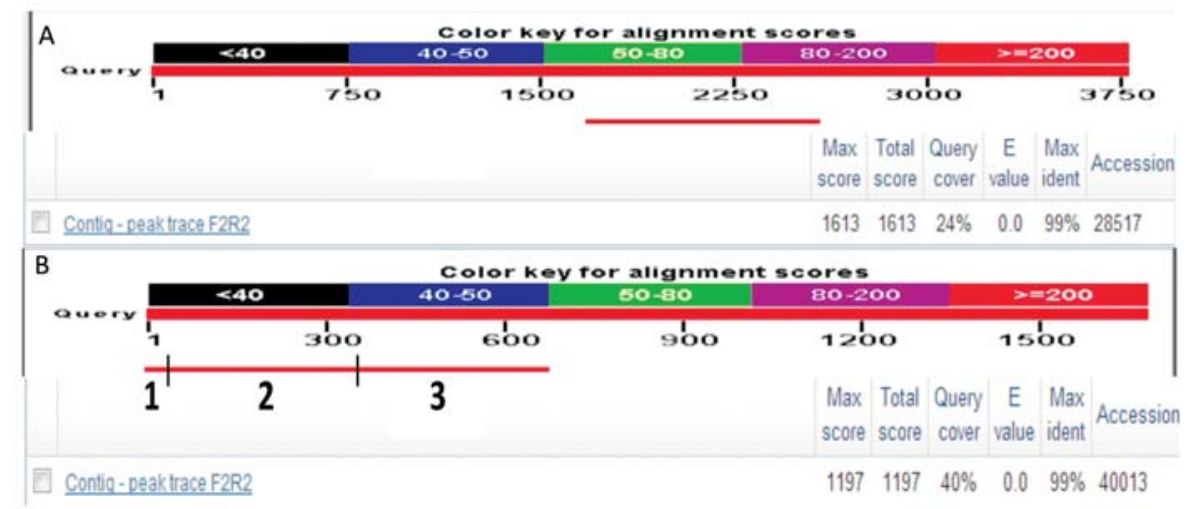

Figure 5. The results of the BLAST sequence AT3 C. frutescens cv. CakraHijau with gene comparison: (A) C. frutescens cv. BG2814-6, (B) C. frutescens cv. Shuanla. 1: F2R2 fragment; 2: F1/R1 fragment; 3: F3R3 fragment.

ClustalX alignment analysis of merged $F 1 / R 1-F 2 / R 2-F 3 / R 33^{\text {rd }}$ ORFamino acid sequence revealed that $F 1 / R 1-F 2 / R 2-F 3 / R 3$ fragment compiled the $1^{\text {st }}$ up to $225^{\text {th }}$ amino acid sequence of $C$. frutescens $\mathrm{cv}$. Shuanla (Figure 6 ). Taking a consideration of F1/R1-F2/R2-F3/ $R 3$ position toward AT3 gene of Capsicum frustescens cv BG2814-6 revealed by BLAST analysis, we suggest that upstream sequence of $C$. frustescens cv. BG2814-6 AT3 gene relatives to both $A T 3$ of $C$. frutescens cv. CakraHijau and Capsicum frutescens cv Shuanla is a promoter region of the respective gene.

Further analysis shows that $F 1 / R 1-F 2 / R 2-F 3 / R 3$ fragment is highly conserved compared to the respective $A T 3$ sequence from both $C$. frutescens $\mathrm{cv}$. Shuanla and $C$. frustescens $\mathrm{cv}$. BG2814-6. There are only three amino acids which are exclusively belongs to $C$. frutescens cv. CakraHijau, i.e. amino acid \#14, 191, 211; with amino acid \#191 is an inserted amino acid compared to both $C$. frutescens cv. Shuanla and $C$. frustescens cv. BG2814-6.

Examining the position of $F 1 / R 1-F 2 / R 2-F 3 / R 3$ fragment relative to both $C$. frutescens $\mathrm{cv}$. Shuanla and $C$. frustescens cv. BG2814-6, possible open reading frame, and taking an account on the amino acid alignment result with those two references, which gives a highly shared amino acid sequences and it is suggested that there is about $900 \mathrm{bp}$ fragment left which has not yet been isolated. There are more works need to be done to retrieve a complete sequence of this gene. 
C. frutescens cv. BG2814-6

c. frutescens cv. Shuanla

c. frutescens cv. Cakra

clustal Consensus

C. frutescens ov. B G2814-6

c. frutescens cy. Shuanla

c. frutescens cv. Cakra

clustal consensus

c. frutescens cy. BG2814-6

c. frutescens cy. Shuanla

c. frutescens cv. Cakra

clustal Consensus

C. frutescens cv. BG2814-6

c. frutescens cy. Shuanla

c. frutescens cv. Cakra

clustal Consensus

c. frutescens cv. BG2814-6

c. frutescens cv. Shuanla

c. frutescens cy. Cakra

clustal Consensus

c. frutescens cv. BG2814-6

c. frutescens cy. Shuanla

c. frutescens cy. Cakra

clustal Consensus

C. frutescens cy. BG2814-6

c. frutescens cv. Shuanla

c. frutescens cy. Cakra

clustal Consensus

C. frutescens cy. B G2814-6

c. frutescens cy. Shuanla

c. frutescens cv. Cakra

clustal Consensus

C. frutescens cy. BG2814-6

c. frutescens ov. Shuanla

clustal consensus
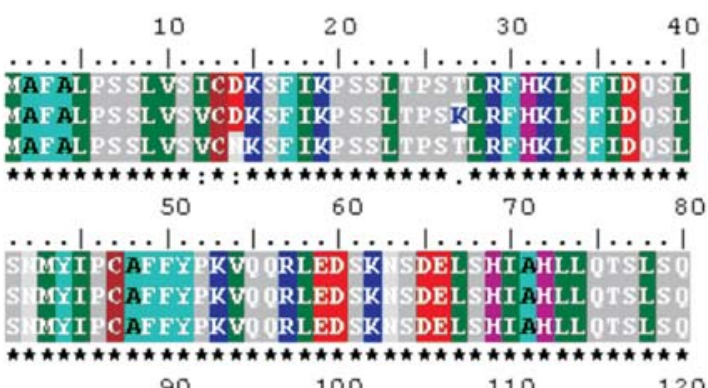

$90100-110$

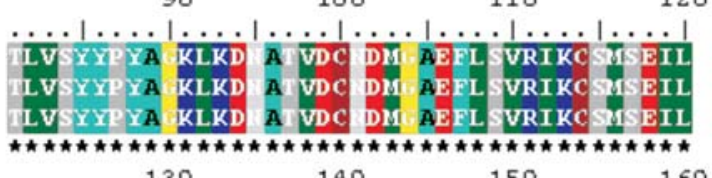

$130 \quad 140$
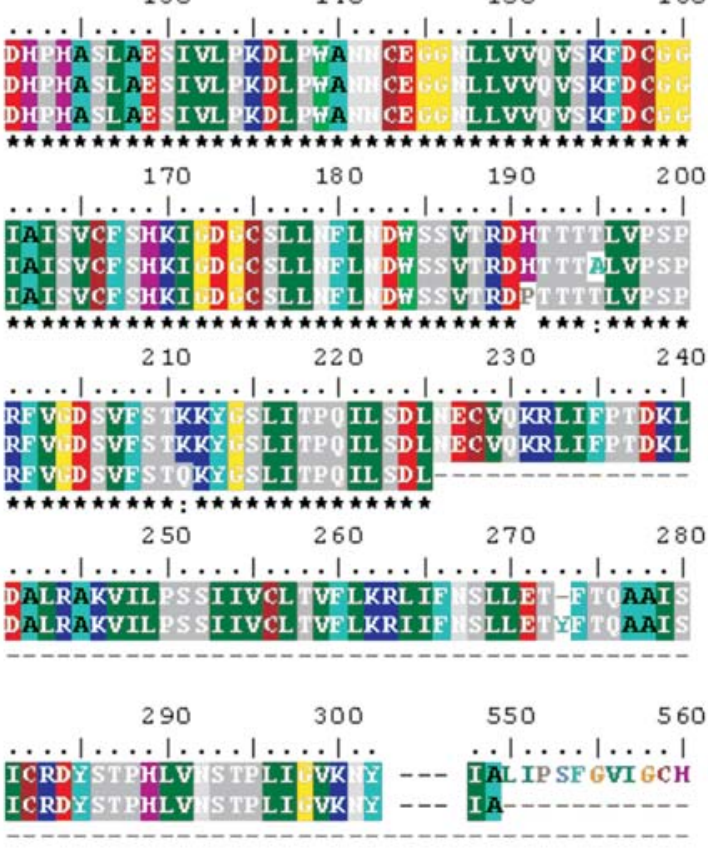

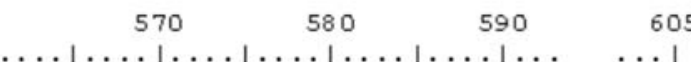

FQVFC GVLKRE GF YE IKEYF NL RHKGRHHL LL C -- TVI

c. frutescens cy. Cakra

Figure 6. Alignment of amino acid sequences of $C$. frutescens $\mathrm{cv}$. CakraHijauAT3 with $C$. frutescens cv. BG2814-6 and C. frutescens cv. Shuanla; Asterisks depict conserved amino acids.

\section{CONCLUSION}

This research combined with previously obtained fragment has successfully isolated as long as $905 \mathrm{bp}$ AT3 gene fragment which is $675 \mathrm{bp}$ length of the 3 ' fragment is suggested to encode a functional part of $C$. frustescenscv CakraHijau AT3 gene. Further research is ongoing in order to retrieve as long as $972 \mathrm{bp}$ of the 3' last fragment to obtain the complete sequence of $A T 3$ gene from Capsicum frustescenscv CakraHijau. A careful primers designing is necessary. 


\section{REFERENCES}

Djarwaningsih, T. 2005. Capsicum spp. (Cabai): Asal. Persebaran dan Nilai Ekonomi. Biodiversitas 6 (4): 292-296.

Rukmana, H.R. 2002. Usaha Tani Cabai Rawit. Yogyakarta: Penerbit Kanisius.

Stewart, C., M. Mazourek, M.S. Giulia, O.C. Mary, and J. Molly. 2007. Genetic Control of Pungency in C. chinensis Via the Pun1 Locus. Journal of Experimental Botany 58: 979-991.

Stewart, C., B.C. Kang, K. Liu, M. Mazourek, S.L. Moore, E.Y. Yoo, B.D. Kim, I. Paran, and M.M. Jahn. 2005. The Pun1 gene For Pungency In Pepper Encodes A Putative Acyltransferase. The Plant Journal 42: 675-688.

Stellari, G.M., M. Mazourek, and M.M. Jahn. 2010. Contrasting modes for loss of pungency between cultivated and wild species of Capsicum. Heredity 104: 460-471.

Kim, M.W., K. Shinje, K. Soohyun, and D.K. Byung. 2001. Isolation of cDNA Clones Differentially Accumulated In The Placenta of Pungent Pepper by Suppression Substractive Hybridization. Molecular Cells 11 (2): 213-219.

Habibi, M., A.M. Manggabarani, E.S. Sulasmi, and D. Listyorini. 2013. AT3 (Acyltransferase) Gene Isolation from Capsicum frutescenscv. CakraHijau. Journal of Tropical Life Science 3(2): $83-86$. 